\title{
Sediment Deformations Due to Paleoseismic Events
}

\author{
Nils-Axel Mörner \\ Paleogeophysics \& Geodynamics, Stockholm, Sweden \\ Email: morner@pog.nu
}

How to cite this paper: Mörner, N.-A. (2019) Sediment Deformations Due to Paleoseismic Events. Open Journal of Earthquake Research, 8, 313-331.

https://doi.org/10.4236/ojer.2019.84018

Received: October 11, 2019

Accepted: November 22, 2019

Published: November 25, 2019

Copyright (c) 2019 by author(s) and Scientific Research Publishing Inc. This work is licensed under the Creative Commons Attribution International License (CC BY 4.0).

http://creativecommons.org/licenses/by/4.0/

\begin{abstract}
There are many different processes generating soft-sediment deformation. This paper is confined to deformations generated by paleoseismic events in Sweden. The Paleoseismic Catalogue of Sweden includes 66 events. The structural characteristics and driving forces of liquefaction are discussed in details. "Crypto-deformations" refer to a special type of fluidization not affecting the sedimentary bedding itself, but the internal orientation of the ChRM and AMS carrying particles. Extensive turbidites are formed at some events. They constitute useful "marker-varves". Out of the 66 paleoseismic events, 31 are dated by varves as to a single year (in one case even to the season of a year). Tsunamites are recorded from 19 of the paleoseismic events; some with wave-heights up to $15-20 \mathrm{~m}$.
\end{abstract}

\section{Keywords}

Deformations, Paleoseismics, Liquefaction, Turbidites, Varved Clay, Tsunamites

\section{Introduction}

The ordering of sediments is the base for stratigraphy, and by that also the base for geology and geochronology (e.g. [1] \& [2]). Ordered sedimentary layering is termed "concordant". When there occurs gaps (Latin: hiatus) in the sedimentary sequence, we talk about "unconformities". Already in the $17^{\text {th }}$ century, the Danish geo-philosopher Nicolò Steno (1638-1686) understood the principles of stratigraphy and post-depositional deformations [3], however.

In most stratal sequences, we also record deformations. Those deformations are usually formed by post-depositional processes (sometimes of syn-sedimentary processes, too). Therefore, sedimentary deformation structures have become excellent archives of post-depositional events. 
In the present paper, I will limit my analysis to paleoseismic deformations as recorded in glacifluvial deposits, annually varved clay sequences, and sea and lake and deltaic deposits in Sweden and surrounding parts of the Baltic and the Kattegatt.

\section{The Paleoseismic Database of Sweden}

The First Paleoseismic Catalogue of Sweden included 52 events (Chapter 12 in [4]). The Second Paleoseismic Catalogue of Sweden included 62 events [5]. Today, it includes 66 events. Their temporal distribution is given in Figure 1. There is a very strong peak amounting to $50 \%$ of all events in the period of maximum rate of glacial isostatic uplift [4]. In the last 5000 years (i.e. the Late Holocene) there are 15 events recorded; [6]).

\section{Deformation Processes}

In seismology, we usually see the first signs of deformations from about M 5.0 5.5. When we are dealing with paleoseismic events, we are restricted to the deformational structures. This means that we are unable to trace events smaller than M 5.

Fault movements represent primary deformation of the bedrock and its covering deposits. Other deformations represent secondary effects. This means the involvement of several other processes to be further discussed below.

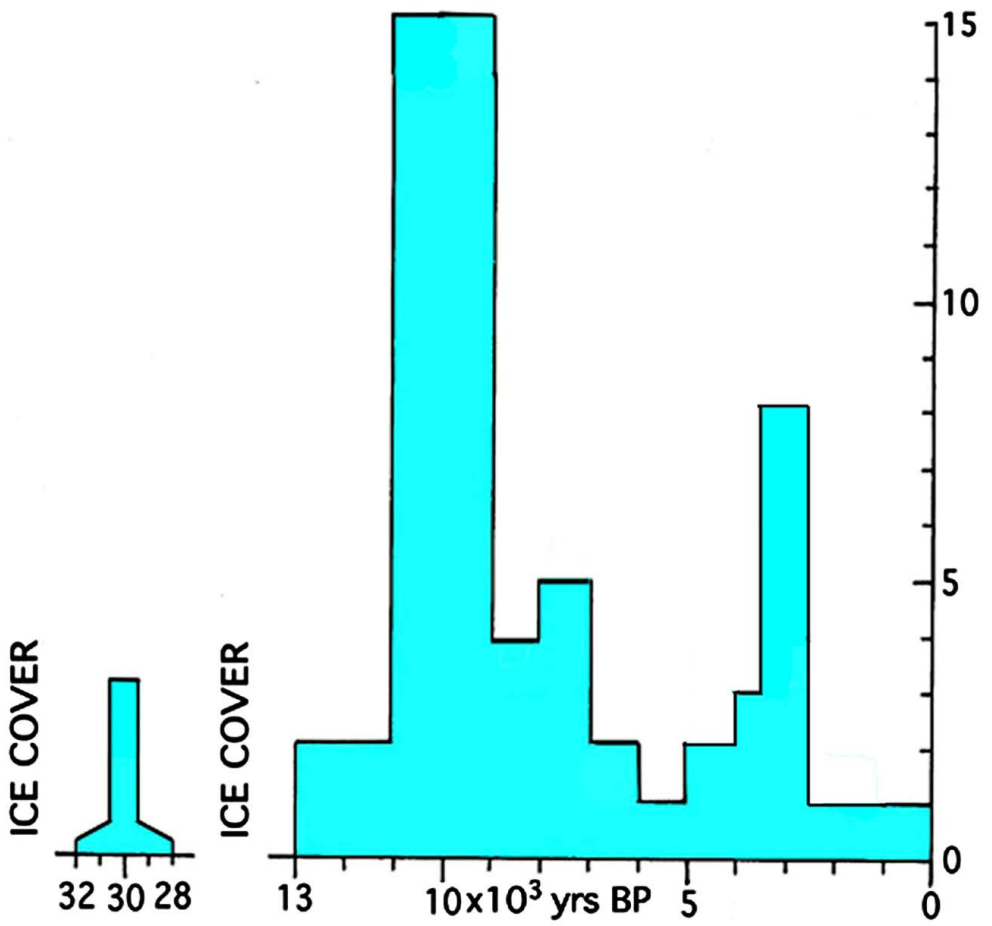

Figure 1. The temporal distribution of observed paleoseismic events in Sweden (66): 50\% of the events occurred during the period of maximum rate of glacial isostatic uplift [4], and $23 \%$ in the Late Holocene [6] with a strong peak at $2500-3500$ BP (which needs its own explanation). 


\subsection{Bedrock Deformation}

Major primary faults in Sweden are for example: the Pärve Fault [7] and Lansjärv Fault [8] in northernmost Sweden, the Hornslandet Fault [4]) in central Sweden, the Mälardalen E-W Fault [4] [9] [10], the Lake Vättern Fault [11] [12] and the Mid-Kattegatt Fault [4] [13].

Besides the main fault deformations, secondary faults and fractures were generated, too. There are examples of quite significant secondary bedrock deformations in Sweden [4] [10] [14] [15].

Bedrock cave deformation is a quite specific type of deformation [15] [16]. Most of them must have a seismotectonic origin [15] [17]. Some of them, however, are caused by methane-venting-tectonics; i.e. they are the function of explosive venting when methane ice is suddenly transformed into methane gas [4] [5] [10] [14].

Massive bedrock avalanches are initiated by earthquake shaking and bedrock fracturing, but driven by gravity. There are quite clear examples of this in Sweden [4] [15] [16] [17].

\subsection{Sediment Deformations}

The main processes of sediment deformations are directly linked to the ground shaking as further discussed below (Section 4). Methane venting is an additional process [4]. Earth slides, initiated by earthquake shaking or methane venting are, of cause, driven by gravity. The Storegga submarine slide outside the Norwegian coast is of enormous dimensions (e.g. [18]), and it is linked to methane venting (e.g. [19]).

There are numerous different processes that may generate sediment deformation, such as: bioturbation, erosion/re-deposition, load-casts, slides and turbidites, sediment adjustments, liquefaction, tsunamis, glacial-tectonics, ice-rafting, and peri-glacial activities (on land). In this paper, I will limit the discussion to deformations of seismic origin, i.e. seismites, recorded in Sweden (cf. [4] [20]).

\section{Sedimentary Deformational Structures}

The structures of deformation are usually indicative of the causation processes. Often there are optional possibilities, calling for additional analyses in order to reveal the true process. It must be stressed that in all cases where I have advocated a seismic origin of observed deformations, this interpretation is backed up by multiple seismic criteria [4] [10].

\subsection{The Family of Seismites}

Everything moved out of primary, in situ, position due to earthquake shaking may be called a "seismite" [20]. Consequently, this includes dislocated rock fragments, rock avalanches, seismotectonic caves, earth slides, liquefaction, tsunamites and turbidites, as illustrated in Figure 2. As to particle size, this implies a range from blocks to clay. Via magnetic methods, we may even record fluidized reorganization of very fine particles in the interstitial water [21]. 


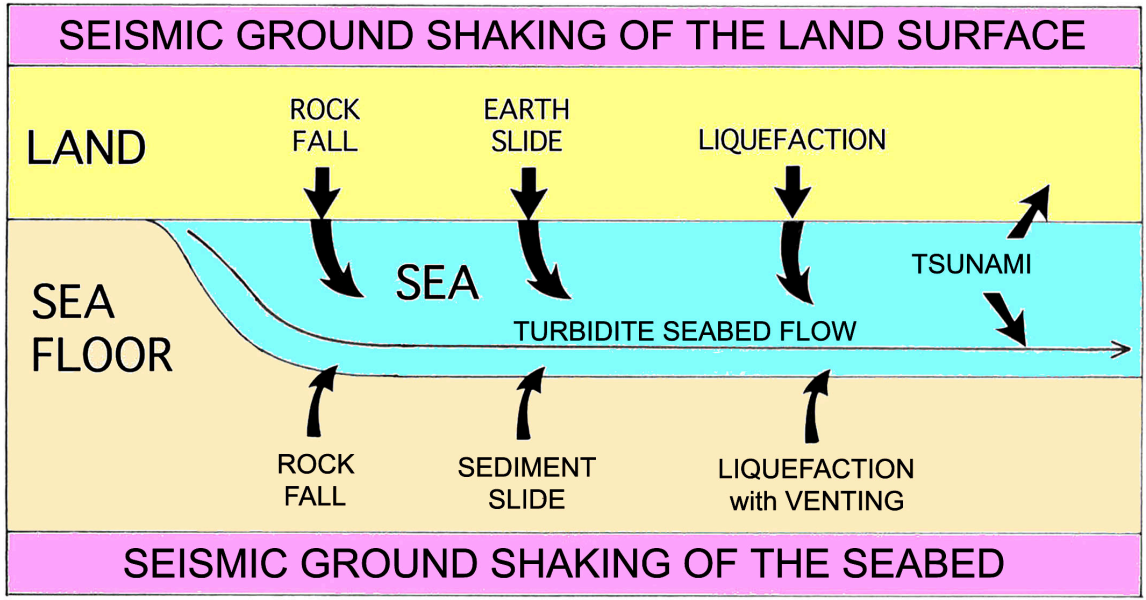

Figure 2. Seismic ground shaking, its feeding and generation of turbidite flows giving rise to special marker-varves or marker-beds, providing an exact dating of the causational paleoseismic event [4]. The model for tsunami induced turbidites is given below in Figure 17 [33].

\subsection{Liquefaction}

Sweden is full of excellent liquefaction structures [4] [22] [23] [24] [25]. Before our studies on paleoseismology at the P \& G-unit of Stockholm University, it was not understood that Sweden had suffered both frequent and high-magnitude earthquake events in the past [11] [26]. Therefore, the structures could not be correctly interpreted. Descriptions to local Quaternary maps of Sweden often show photos of deformed sediments labelled "water escape structures". Now, we know that these pictures record quite clear liquefaction structures ([4] e.g. the remarkable site of Olivelund, pp. 234-236). In another case, quite typical liquefaction structures ([4] the Hunnestad site, pp. 281-282, later more fully described in [13]) were even termed "an ice wedge". We therefore had to start, so to say, from the beginning, and there is a general lack of comparative studies in Sweden (except for [27] and [28]).

The phenomenon of "liquefaction" refers to the process where a sediment layer or a part of a sediment layer is transformed into a fluid or fluidized stage (from Latin: liquid facere). This occurs post-depositionally (sometimes also "syn-sedimentary"). There are different ways of generating liquefaction. The most common process is earthquake shaking [25].

The shaking motions at an earthquake may lead to a reorganisation of the internal distribution of grains and water so that the sediment becomes fluid. This makes deposits of sand and course silt most susceptible for liquefaction. Also, fine gravel may fairly easily become liquefied. Liquefaction of courser and finer sediments (course gravel to pebbles and fine silt to clay) only occurs rarely and under special conditions. The post-depositional liquefaction of a stratified sandy bed implies that the original stratification becomes totally or partly erased into a structureless bed (Figure 3). By magnetic methods, we have shown that also clay and fine silt beds may be subjected to an internal fluidization [21]. 


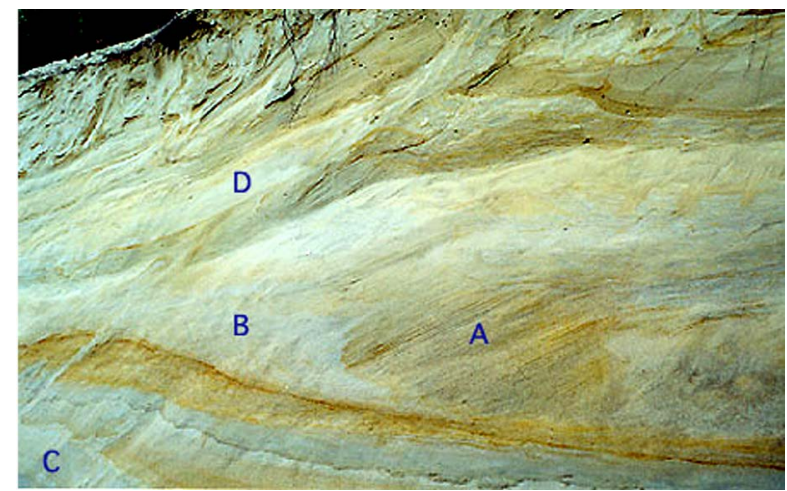

Figure 3. The primary bedding (A) has become erased by liquefaction into a structureless bed (B). Beds (C) and (D) of structureless sand refer to a 2nd and 3rd phase of liquefaction with venting (from [4]; site Olivelund). This event occurred in the autumn of varve $10,430 \mathrm{BP}$.

A liquefied bed will behave like a "heavy fluid" allowing big blocks and eroded fragments to "swim" in the liquefied bed (Figure 4). This also opens for density redistribution heavy beds sinking down and lighter beds flaming upwards (Figure 5). This also leads to venting of liquefied material and formation of mud-volcanoes. The size of venting structures and the material to become vented are strongly linked to the magnitude of earthquake.

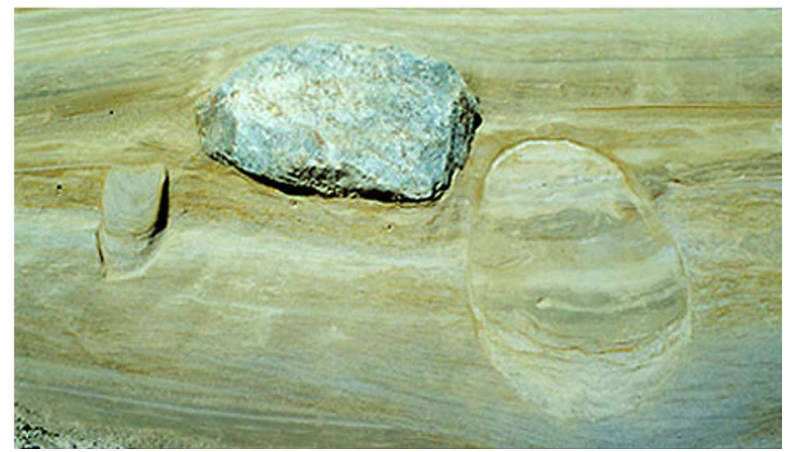

Figure 4. Liquefied sand behaving like a "heavy fluid," in which blocks may "swim" (detail from [4]; site: Olivelund).

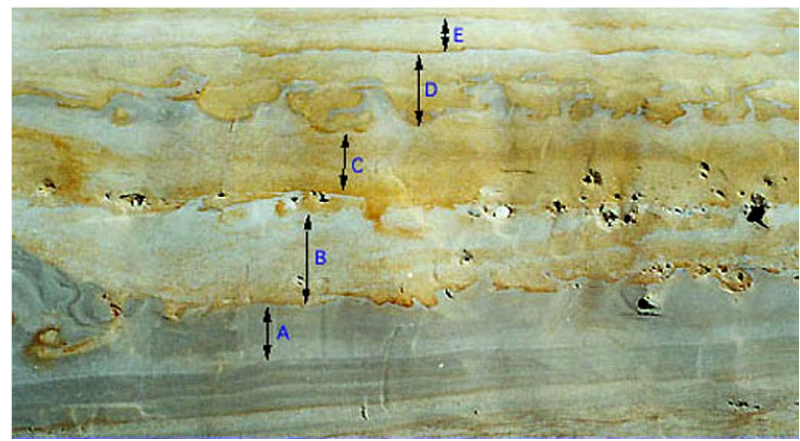

Figure 5. Five sedimentary cycles (A-E) affected by post-depositional liquefaction in varve year $9428 \mathrm{BP}$ causing the fine sediments to flame upwards and the course sediments to sink downwards (detail from [4]; site Rödbäck). 
Liquefaction may strike a stratified sedimentary bed quite differently; strongly deforming some beds and leaving others virtually unaffected (Figure 6). The material vented or liquefied behaves quite differently with respect to grain sizes. Whilst the material forming the vented or liquefied structure is primarily flow-oriented, the micro-particles may be randomly or magnetically re-oriented as further discusses under crypto-deformations.

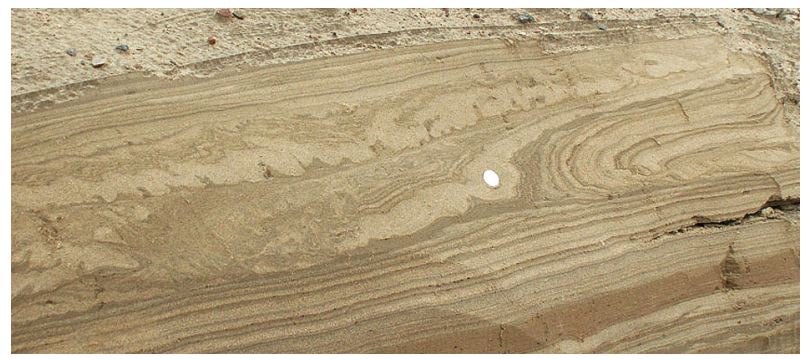

Figure 6. Differential liquefaction of a stratified bed at a paleoseismic event at 12,400 [4] [13].

Also laterally, the liquefaction strikes sedimentary beds quite differentially. So, for example, did we record only vaguely deformed varves in a shallow trench, but totally mess of heavily liquefied deposits in a $2 \mathrm{~m}$ deep trench only $20 \mathrm{~m}$ away ([21] site: Mehedeby).

Because earthquakes usually are not single events, but rather a cluster of shocks and after-shocks, one would expect to see not just one phase of liquefaction, but multiple phases [4]. Therefore, it seems significant that we, at several events, were able to record multiple phases of liquefaction. At the $9663 \mathrm{BP}$ paleoseismic event, we recorded five successive phases (Figure 7) in two sites located $35 \mathrm{~km}$ apart, and interpreted those phases in terms of shock and after-shocks.

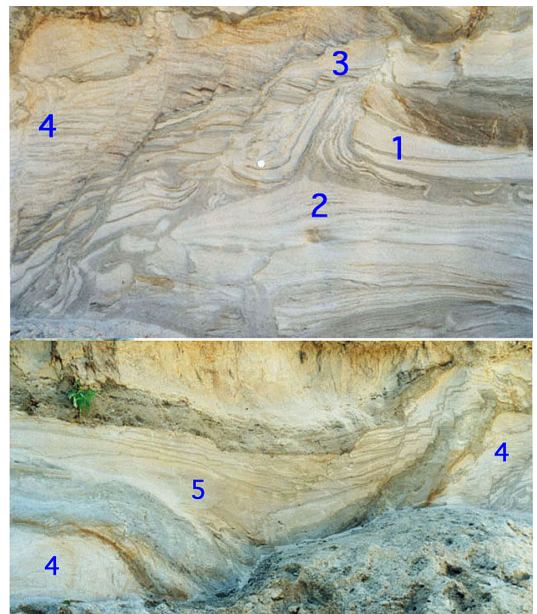

Figure 7. Five successive phases (1 - 5) of liquefaction of the 9663 varves BP paleoseismic event, interpreted to represent shocks and after-shocks of the same earthquake event (from [4] [9]; site: Myra West). Five successive phases were also recorded at a site located $35 \mathrm{~km}$ away in exactly the same varve year (op. cit., site: Hög). 
The size and type of liquefaction structures have a bearing on the magnitude. In some cases we have recorded the venting of gravel, even course gravel and pebbles (Figure 8). This calls for magnitudes in the order of $M>8$. One such event is dated at 10,388 vBP and another at $6100 \mathrm{BP}$ [4] [9] [24] [25].

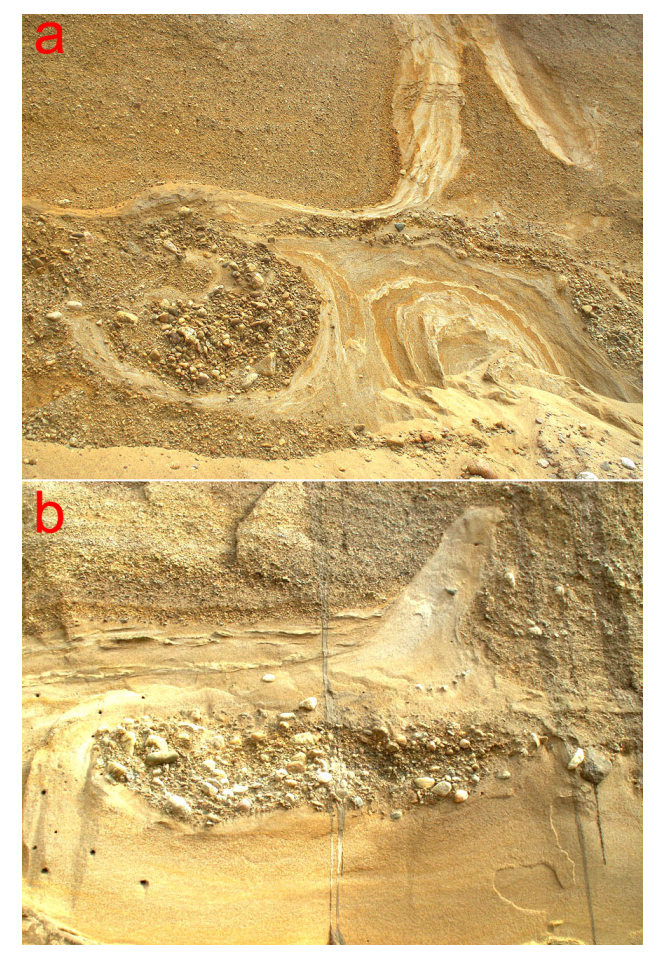

Figure 8. Venting not only of liquefied sand (b) but also gravel and pebbles (a) at the 10,388 vBP event ([4] [9]; site Turinge grusgrop). Venting of such coarse material calls for a high-magnitude paleoseismic event $(M>8)$.

The spatial distribution of a liquefaction event is more or less linearly related to the magnitude of the earthquake (Figure 9). Liquefaction events are recorded at numerous sites in Sweden [4] [9] [24] [25].The spatial distribution of one and the same liquefaction event gives evidence of high-magnitude paleoseismic events. The paleoseismic event occurring in the autumn of varve 10,430 BP generated liquefaction over an area of $320 \times 100 \mathrm{~km}$, and the event in varve $9663 \mathrm{BP}$ over an area of at least $80 \times 40 \mathrm{~km}$, which can be used to estimate the corresponding magnitudes according to Figure 9 . It is the time resolution as to a single varve (even season of a varve) that allow us to reconstruct the past spatial distribution of liquefactions, and by that of obtaining a magnitude estimate [4] [10].

Even the frequency of paleoseismic varves was unusually high. So for example, 7 events were recorded with 102 years ranging from varve 10,490 to $10,388 \mathrm{BP}$ [9] [10].

Liquefaction events are also recorded in Late Holocene deposits. An event causing strong liquefaction is dated $4800 \mathrm{BP}$ [4] [6] [10], and a younger event of about $2800 \mathrm{BP}$ generated liquefaction at sites $52 \mathrm{~km}$ apart [29]. 


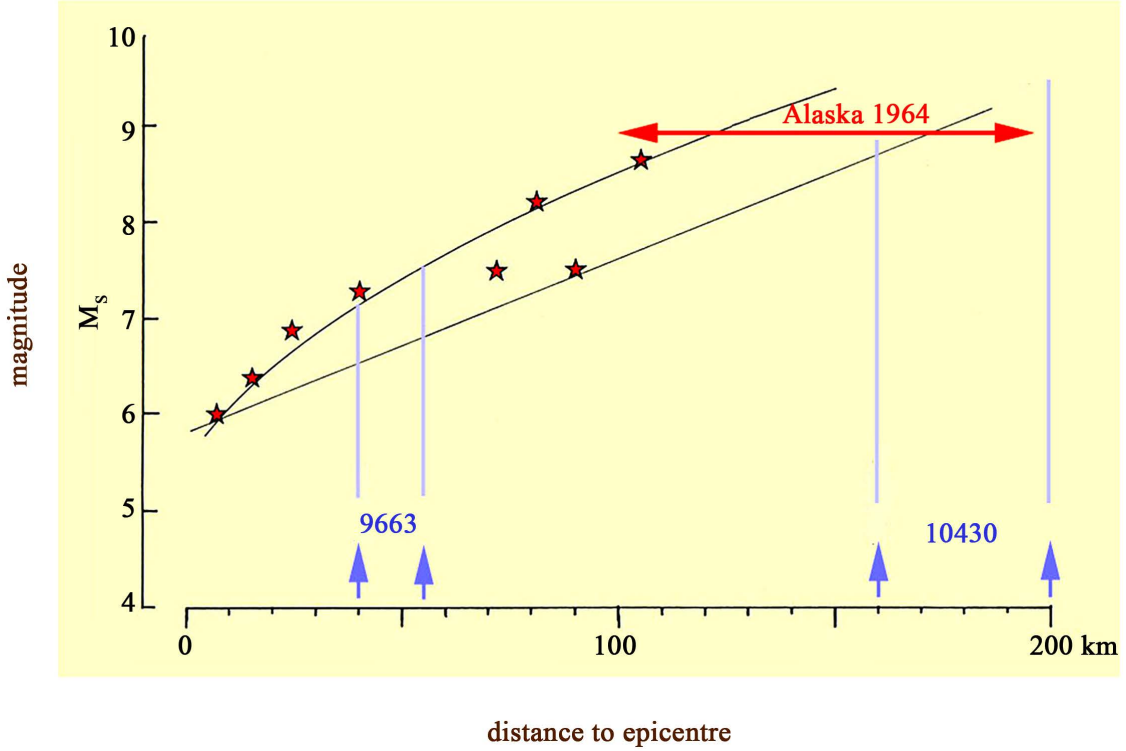

Figure 9. Relations between spatial distribution of liquefaction and earthquake magnitude. The liquefaction area of the 9663 event corresponds to a magnitude of M 7.2 - 7.4, and the area of the 10,430 event to a magnitude of M $8.7-9.3$. These estimates are then compared with other information in order to arrive at the most likely magnitude estimate [4] [10] [13] [37].

The seismic wave passing over a site generates an expansion/contraction pumping effect, recorded both in bedrock and in sediment deformations [4]. At two sites in [4] (viz. at Hög, pp. 122-132, and at Olivelund, pp. 234-236), we recorded a wavy pattern in the top of the deformed and liquefied sedimentary sequence; in Hög the wavelength was in the order of $2-3 \mathrm{~m}$ and in Olivelund of about $50 \mathrm{~m}$ (Figure 10).

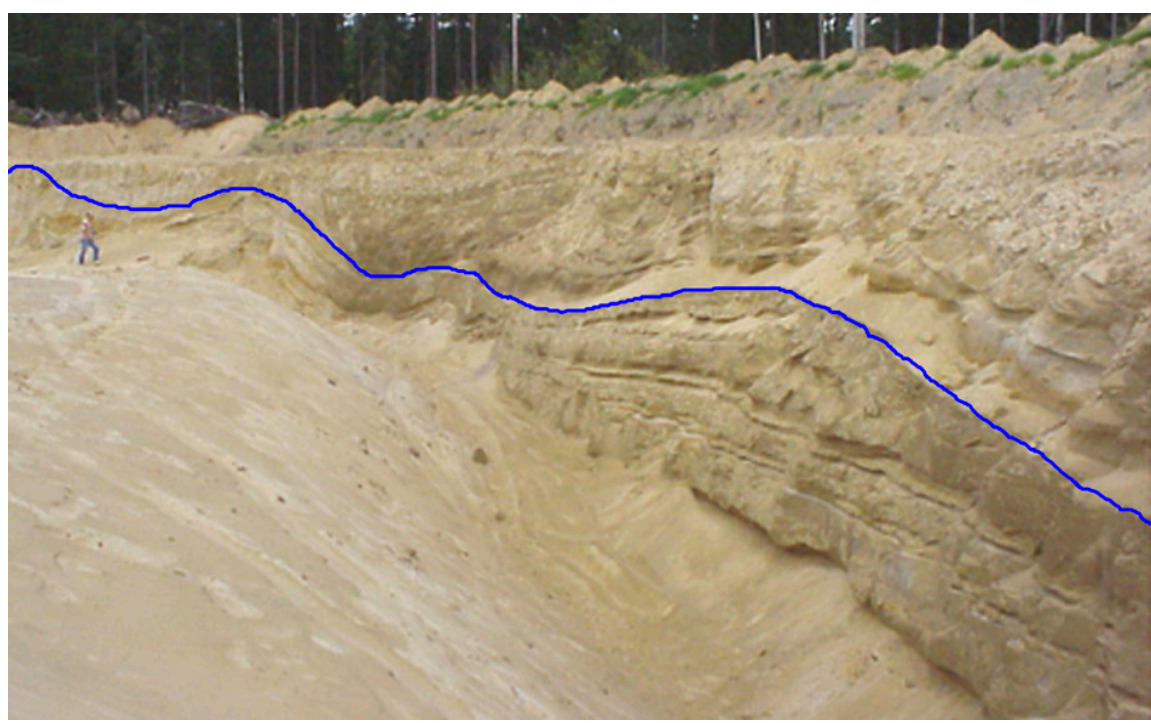

Figure 10. Waves of $1-2 \mathrm{~m}$ height and about $50 \mathrm{~m}$ wavelength thought to be a fossil imprint of the seismic wave passing the site (from [4], site: Olivelund). Liquefied material is concentrated under the wave crests. 
Seismic shaking may also generate wavy patterns of previously horizontal sand and clay beds (Figure 11; cf. [4] and [21]). The combination of liquefaction fluidization and ground shaking also generated the sinking down of pebbles and stones in the liquefied beds of sand below as shown in Figure 12.

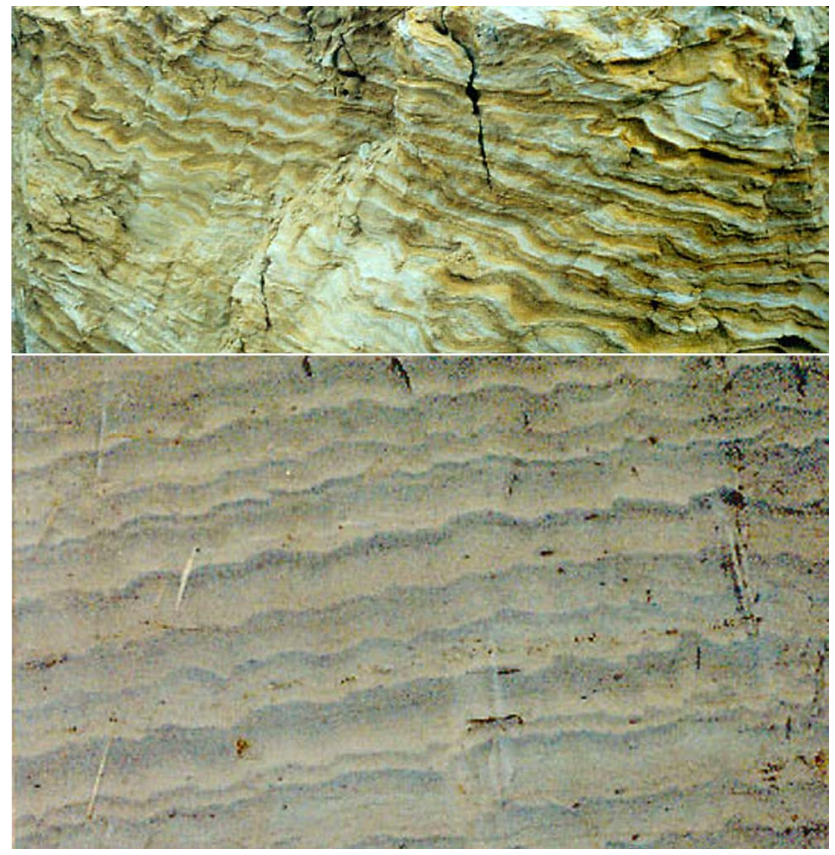

Figure 11. Seismic ground shaking may sometimes generate wavy patterns in sand (above) and clay (below) (from [4]). The wavy clay layers have increased paleomagnetic intensity suggesting internal fluidization [21].

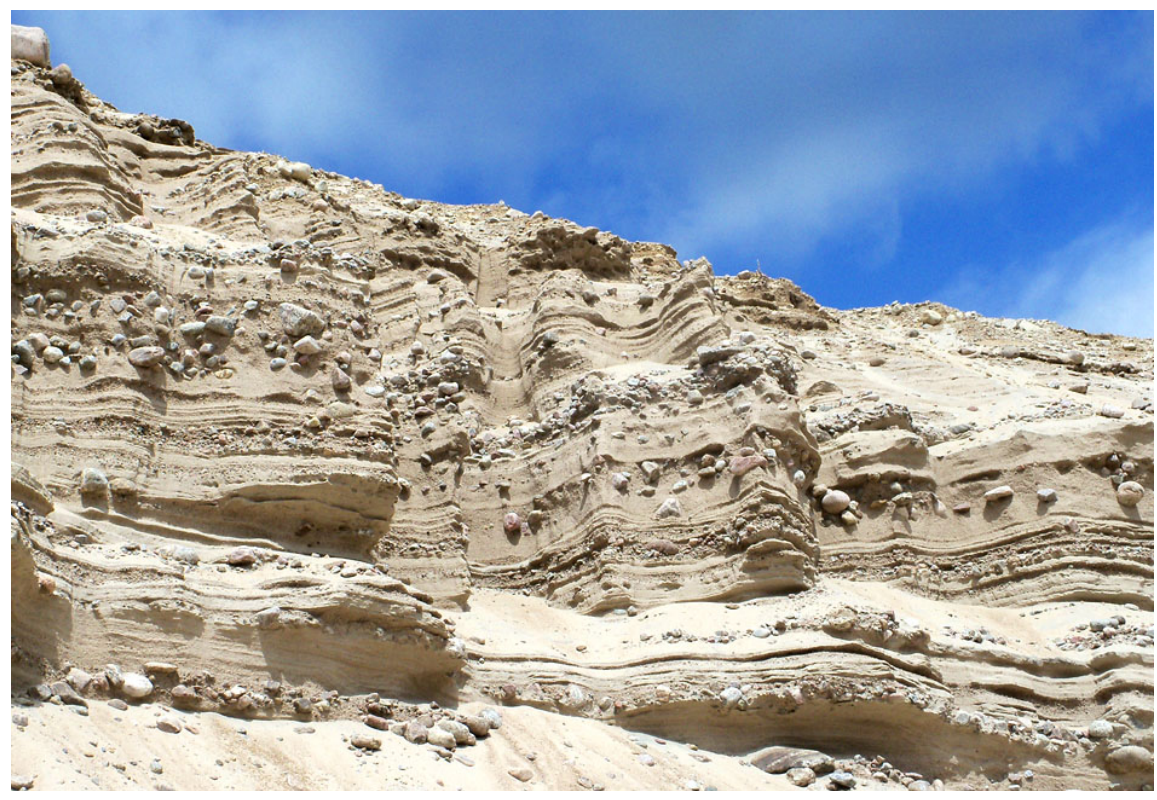

Figure 12. The 12,400 BP paleoseismic event on the Swedish West Coast generated heavy liquefaction at Hunnestad [13]. The sand beds became liquefied allowing the stones to sink down into the fluidized beds. The deposits were originally formed as a deltaic accumulation in front of the ice margin. 
When sediments become liquefied and the fluid masses move and vent, covering sediments have to accommodate for the space changes. This gives rise to additional deformations and micro-faulting of sedimentary units dislocated as illustrated in Figure 13.

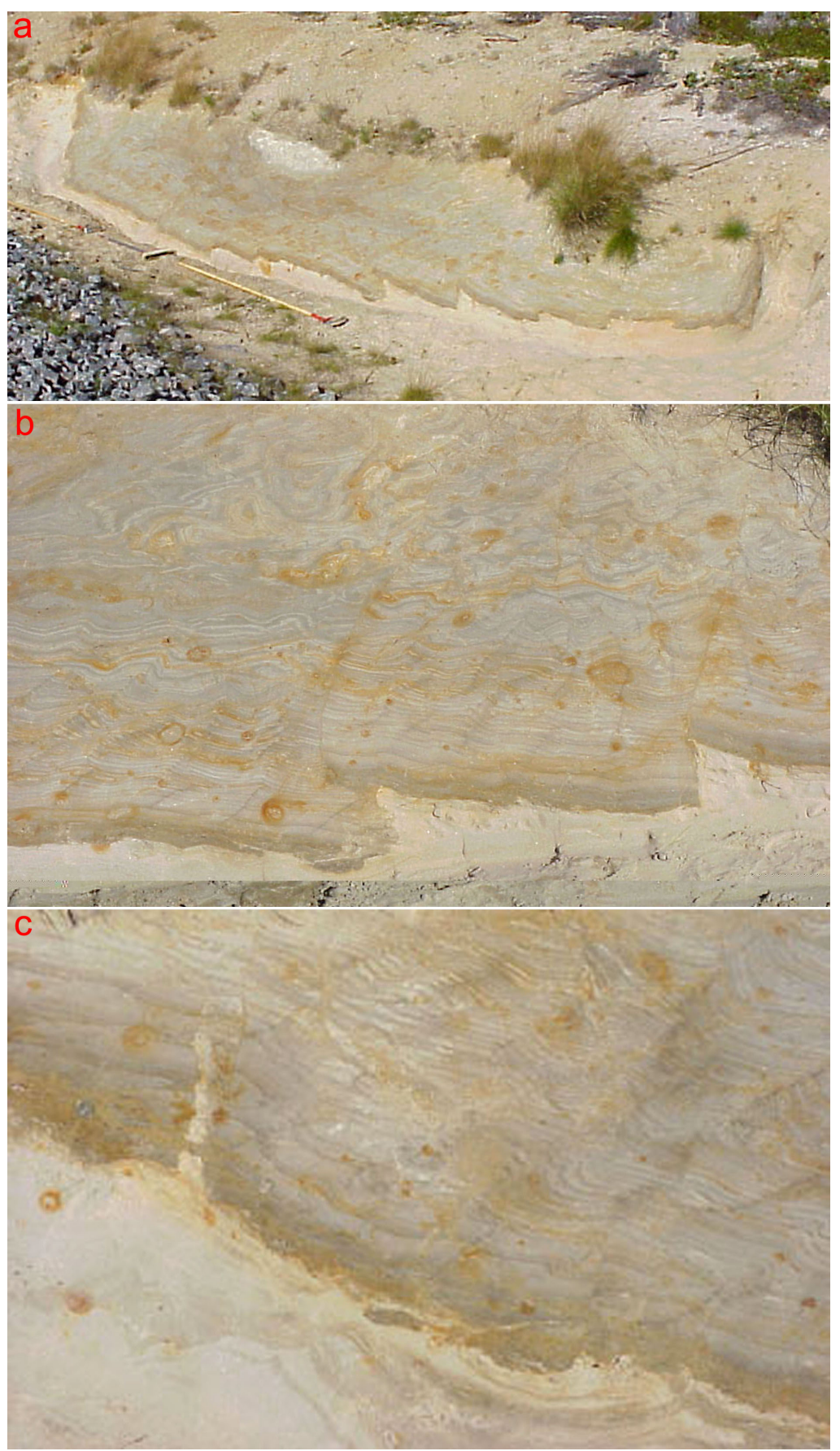

Figure 13. A bed of totally liquefied varved clay has sunk down into a bed of liquefied sand (a). At this space accommodation, the eastern side (right) became faulted (b). In the western side (left) we see a venting pipe and clay fragments sinking down into the liquefied sand (c). The liquefaction event is dated at 9663 BP [4], and includes two phases of liquefaction. 
Extensive turbidites are often formed by the sediment masses set in motion by slides, liquefaction and tsunami waves (Figure 2). They stick out as distinct "marker-varves" (Figure 14). This allows a very precise dating with respect to the Swedish Varve Chronology (e.g. [30]).

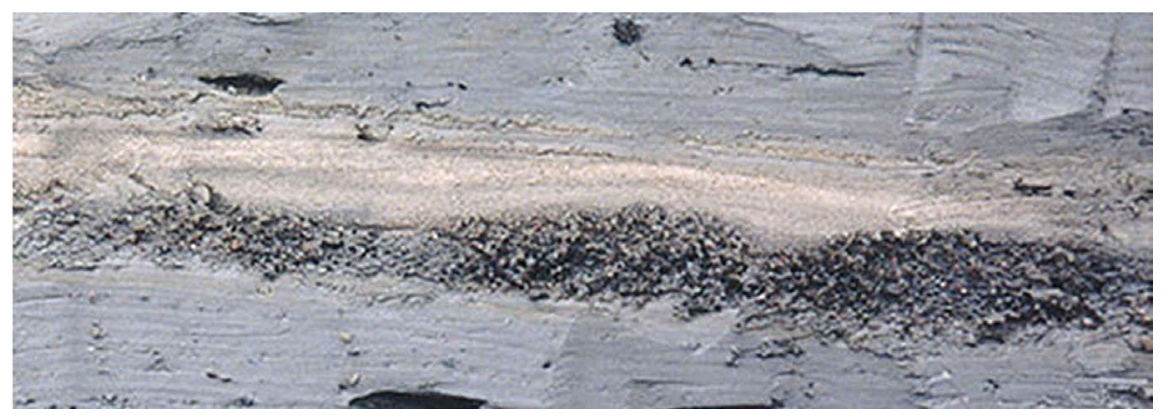

Figure 14. The 9663 vBP turbidite (seismite) of graded bedding, here seen as a distinct marker-bed within an annually varved clay at a position 119 varves after deglaciation in full agreement with a varve age of $9663 \mathrm{BP}$ [4].

\subsection{Varve Deformation and Dating}

The clay deposited in the Baltic basin in front of the receding ice margin became annually stratified in grains-size, colour and geochemical content. By counting the varves, De Geer [31] was able to build up a chronology for the last 10,000 12,000 years, known as The Swedish Timescale. After intensive additional work and revisions by numerous scientists, the time-scale now covers about 14,000 years (e.g. [30]).

The turbidites of the paleoseismic event of 10,430 and 9663 varves BP are both varve specific and provides direct dates. Out of the 62 paleoseismic events included in the Second Paleoseismic Catalogue of Sweden [5], 31 events are dated by varves.

In the Stockholm area, 4 subsequent paleoseismic events were recorded and due to their deformations of varves dated at 10,490,10,469, 10,447 and 10,430 varves BP ([4] p. 229-232), implying a recurrence time of about 20 years. Including the more westerly parts of the E-W fault passing the Lake Mälaren area, the sequence of paleoseismic events was later updated at 7 events within 102 years (see Figure 10 in [10]).

The 10,430 varve BP event is special, because in this case we can assign a seasonal resolution to the autumn of this varve [4] [9] [10] [20] [32]. In 3 sites over a distance of $76 \mathrm{~km}$, the earthquake event is pinpointed to the autumn of the varve 10,430. This is illustrated in Figure 15 (to be compared with the actual sedimentary columns in Figure 6 of [20]). Section A1 shows a concordant stratigraphy with a change from freshwater to brackish water varves at the varves 10,431/10,430 transition, which corresponds to a major tsunami event opening a free connection to the Atlantic [4] [34]. Section A2 shows an erosional depression, which began to be filled by the autumn unit of varve 10,430 (indicating the 
return to normal sedimentary conditions after the paleoseismic event and tsunami event). Section B (Lake Albysjön) shows a slump injected into the autumn unit of varve 10,430. Section C (Lake Dammsjön) shows a strongly irregular and flamelike autumn unit of varve 10,430 (the summer and winter units remaining homogeneous).

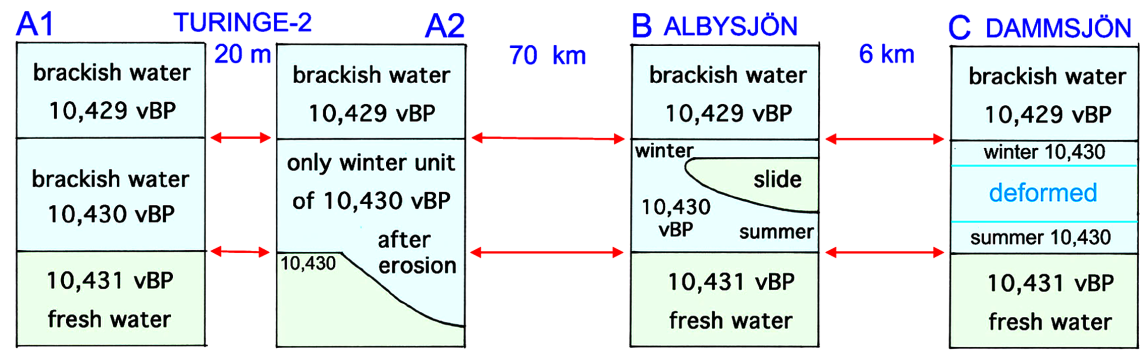

Figure 15. The paleoseismic event and turbidite of varve year 10,430 BP have been recorded in hundreds of sections and cores in southern Sweden. In three sites distributed over an area of $76 \mathrm{~km}$, the occurrence of the earthquake event could be pinpointed to the autumn season of varve 10,430 BP [4] [20]. The change from fresh water to brackish water conditions in the Baltic represents a simultaneous tsunami event washing the connection to the Atlantic free of pack ice.

\subsection{Tsunamites}

The first record of a tsunami event was found in 1995. This event was linked to the 10,430 varves BP paleoseismic event. It was followed by the discovery of a tsunami event linked to the 9663 varves BP event. After preliminary reports [33] [35] [36], the full report followed [4], [33] and [36]. The relation between tsunami wave height and earthquake magnitude is given in [37]. A general account of tsunami deposits is given in [38].

Up to now, a total of 19 events have been documented and described in Sweden (Table 1). They are traced both in on-shore environment as intra-clay sand-layers containing a planctonic microfossil fauna and flora, and in offshore environment as extensive turbidites (below). In all cases, the tsunami events can be linked to other records of paleoseismic events, such as liquefaction and bedrock deformation [4] [33] [36].

At the 9663 varves BP paleoseismic event, we have traced the ingression of a tsunami wave in 14 separate lakes spanning an area of $175 \times 25 \mathrm{~km}$. The wave height must have been, at least, $15 \mathrm{~m}$. The tsunami deposits consist of sandy layers of graded bedding (fining upwards) within clay beds, implying an interruption in the normal depositional conditions. The microfossil content is planktonic indicating an open sea or lake origin. Sometimes, we see a sequence of multiple graded bedding units from a train of tsunami waves.

The 10,430 BP paleoseismic event set up a very strong tsunami, washing the Närke Straight free of pack-ice so that the entire Baltic basin turned brackish within 1 single year [4] [33] [36]. The wave height must have been in the order of $15-20 \mathrm{~m}$. The event is recorded in 9 sites covering an area or $320 \times 200 \mathrm{~km}$. 
Table 1. Tsunami events recorded in Sweden, all in association with paleoseismic events.

\begin{tabular}{|c|c|c|c|c|}
\hline No. & Age in $\mathrm{BP}$ & Area affected & Earthquake magnitude & Observed tsunami record \\
\hline 1 & 12,400 & Kattegatt & At least 8 & Very high and strong wave \\
\hline 2 & 11,600 & Kattegatt & At least 7 & High wave \\
\hline 3 & 11,250 & Kattegatt & About 7 & High wave \\
\hline 4 & 10,430 & Mälardalen & Well above 8 & Very high and strong wave \\
\hline 5 & 10,388 & Mälardalen & Above 8 & Very forceful wave \\
\hline 6 & 9663 & Hälsingland & Above 8 & At least $15 \mathrm{~m}$ wave height \\
\hline 7 & 9428 & Umeå & At least 7 & (Height unknown) \\
\hline 8 & 9291 & Umeå & $7-8$ & At least some metres \\
\hline 9 & 8600 & Södermanland & $6-7$ & Probably some 5 - $10 \mathrm{~m}$ \\
\hline 10 & 7800 & Stockholm region & At least 6 & Maybe $13 \mathrm{~m}$ run-up \\
\hline 11 & 6100 & Hälsingland & At keast 8 & At least $10-15 \mathrm{~m}$ height \\
\hline 12 & 3000 & Umeå & 7.8 & $11 \mathrm{~m}$ \\
\hline 13 & 2900 & Hudiksvall & $\mathrm{MVT} \approx 8.0$ & $12 \mathrm{~m}$ wave height \\
\hline 14 & 2900 & Northern Uppland & $>6$ & $>6 \mathrm{~m}$ run-up \\
\hline 15 & 3000 & Enköping & $\sim 8$ & $13.5 \mathrm{~m}$ \\
\hline 16 & 3000 & Lake Marviken & $\sim 7$ & Local to regional \\
\hline 17 & 3000 & Nynäshamn & $\mathrm{MVT} \approx 8.0$ & $15-20$ m run-up \\
\hline 18 & 1600 & South Kattegatt & Unknown & Some metres run-up \\
\hline 19 & 900 & South Kattegatt & Around 7 & (Height unknown) \\
\hline
\end{tabular}

At about 2900 BP, a major tsunami wave was set up by an explosive sudden venting of methane gas [4] [6] [33] [36], and at around $900 \mathrm{BP}$ an about M 7 paleoseismic event set up a tsunami that covered two Viking-ships with a thick silt bed [36].

Figure 16 gives an instructive example of the interaction between paleoseismic liquefaction and a tsunami event. The ice receded in the varve $9747 \mathrm{BP}, 84$ annual varves were deposited, and then the $9663 \mathrm{BP}$ paleoseismic event occurred causing both liquefaction and a tsunami. The sandy deposits of the events in question are covered by micro-varves and Baltic clay (and finally a cap of littoral sand from the emergence).

The basal silt became liquefied by the 9663 BP paleoseismic event, vented through clay bed (also sending injections horizontally in-between some of the varve units), and mushroomed at the seabed, where it interacted with a tsunami wave. We cleaned the lower clay surface in Pit 4 , and exposed furrows and wave patterns indicating that the tsunami came from the open sea to the east (i.e. from the right to the left in Figure 16). Subsequent studies confirmed that the epicentre was located to the east along the Hornslandet Fault [4]. 


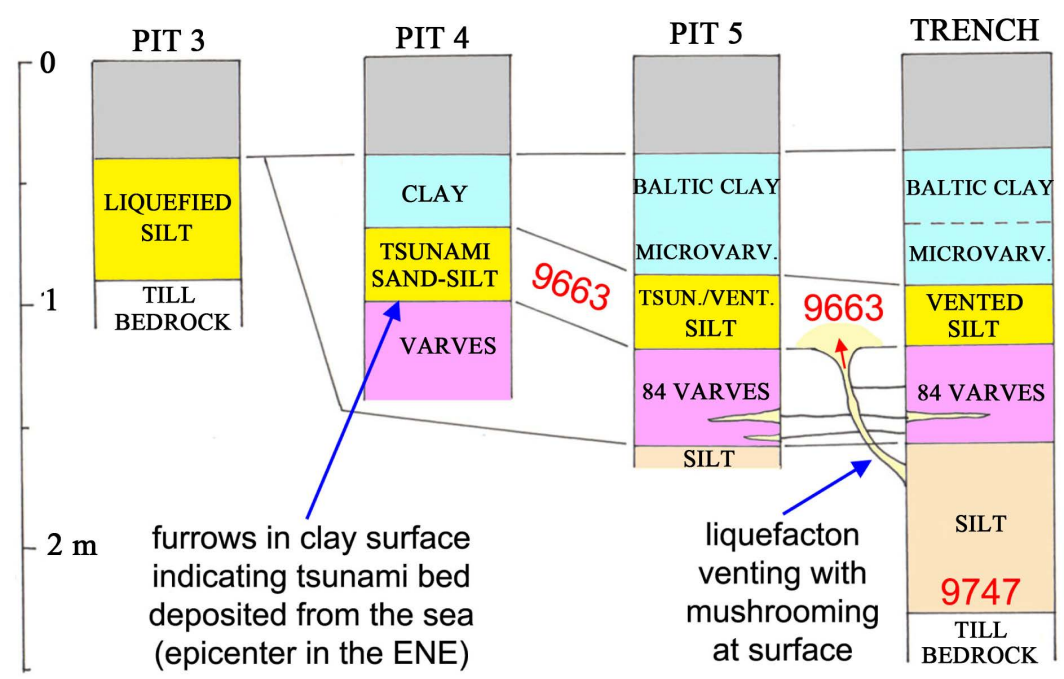

Figure 16. In a number of pits and a major trench at Iggesund Harbour [4], we recorded the interaction of strong liquefaction with venting and mushrooming at the surface, and the deposition of a tsunami bed from a wave arriving from the epicentre $12 \mathrm{~km}$ to the ENE (as evidenced by marks in the clay surface of Pit 4).

\subsection{Turbidites}

Major turbidites occur in varves 10,430, 9663 and 9428 BP. Originally, they were all interpreted in terms of so-called "drainage varves" [32]. Because of their direct association with major paleoseismic events, we can now be sure that they all are turbidites generated by strong paleoseismic events [4] [20] as illustrated in Figure 2. Hence, they are seismites (Figure 12).

These turbidites have been recorded in numerous cores and section over wide areas; $300 \times 200 \mathrm{~km}$ for the 10,430 BP event and $320 \times 90 \mathrm{~km}$ for the $9663 \mathrm{BP}$ event. The mode of deposition seems to be a combination of gravity driven density flow along the bottom (Figure 2) and seabed trimming by tsunami waves according to the model proposed by [33] [36] as shown in Figure 17.

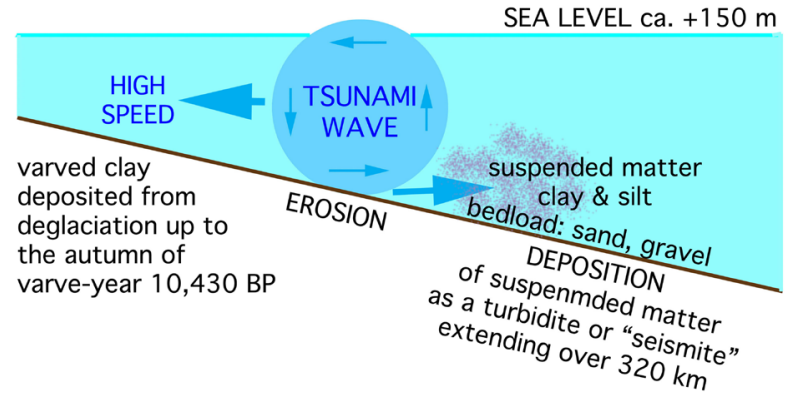

Figure 17. Model of the erosional seabed trimming of the tsunami wave at 10,430 BP [33]. In the autumn of varve $10,430 \mathrm{BP}$, a major tsunami wave rapidly moved laterally from the epicentre. It generated the deposition of an extensive turbidite (also to be termed a tsunamite or seismite) recorded over an area of $200 \times 320 \mathrm{~km}$. The same mechanism seems to have worked at the deposition of the $9663 \mathrm{BP}$ seismite/tsunamite in the Hudiksvall-Söderhamn area (only sea level was there at about $+230 \mathrm{~m}$, implying a larger diameter of tsunami wave). 


\subsection{Crypto-Deformations}

By magnetic methods, it has been possible to detect internal "crypto-deformations" not visible in structural deformations [21] and [39]. I will here give four different cases from Sweden.

A folded structure may originate from a plastic deformation due to glacial-tectonics or slide movements. It may also be generated by liquefaction. In the case of a plastic fold, the turned over part should have a reversed inclination. In the late 90s, I noted that a fold in association with a paleoseismic event in south-central Sweden had normal inclination also in the over-turned part (Figure 18). I took this as evidence that the fold was a liquefaction structure formed under so fluidized conditions that the magnetic grains were able to move freely and could be re-oriented with respect to the magnetic forces. This provided a new method of discriminating between plastic and fluid folds [21].

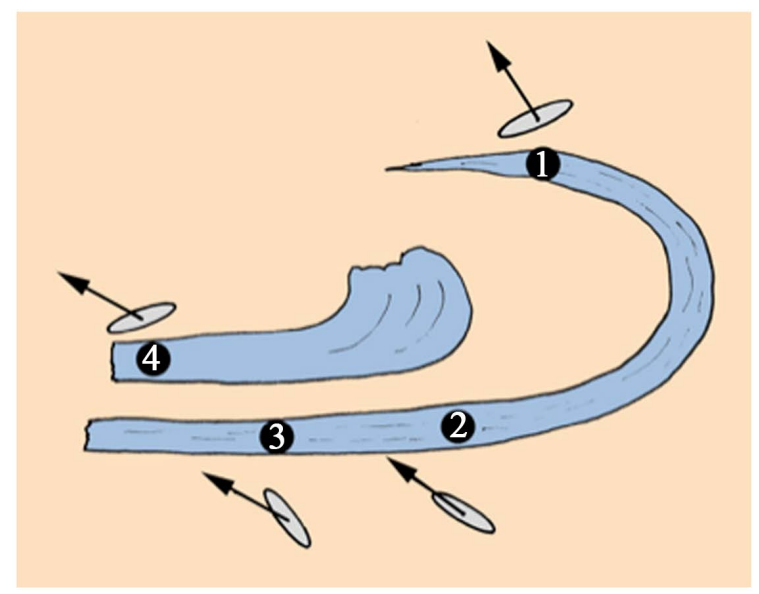

Figure 18. In a plastic deformation, sample 1 should have had a reversed paleomagnetic polarity. This is not the case, all four samples have virtually the same polarity. The reason for this must be that the fold structure was formed under fluid conditions; i.e. liquefaction [21]. Arrows mark direction of declination. Ellipsoids give direction of the long axis of AMS.

In a sequence of 34 concordant varves preceding the 10,430 BP paleoseismic event, we recorded a $90^{\circ}$ eastward rotation of the ChRM values in the lower 20 varves. This must imply that the ChRM carrying grains were moved by the earthquake shaking in a rotational manner increasing upwards by $90^{\circ}$, the AMS carrying grains being aligned with the main depositional flow direction and the varves being virtually un-deformed.

In a major venting mushroom structure of the $9428 \mathrm{BP}$ paleoseismic event, we observed an inward-upward-outward flow of the sandy-silty mushroom structure itself, a totally random distribution of the AMS grains and a perfectly geomagnetic field orientation of the ChRM carrying very fine particles of the interstitial water. Consequently, the earthquake shaking generated a laminar flow of the mushroom itself, a turbulent flow of the AMS particles, and a free flow of the very fine ChRM carrying particles. 
Finally, we noted that the earthquake shaking and free liquid motion of ChRM particles implied a second chance of alignment with respect to the geomagnetic field. Therefore, we noted a spike of increased paleomagnetic intensity, decreasing laterally from the epicentre. We termed this additional magnetization: "seismomagnetization". At the paleoseismic event 10,430 BP, such an intensity peak ("The Gålö Intensity Peak") is recorded over an area of $500 \times 600 \mathrm{~km}$. This is a remarkably large area, and can only be understood in terms of a very strong earthquake event: $\mathrm{M}>>8$ [4] [10].

When we see no visible sedimentary deformation and the AMS and/or ChRM grains are deformed, we may speak of "crypto-deformations" [21].

\section{Conclusions}

Because of the postglacial land uplift, large areas of Sweden represent a former shelf environment with a water depth up to more than $200 \mathrm{~m}$. From present shelf areas, we only have fragmentary records of paleoseismic deformations. In Sweden, however, we have a very complete record because we can work in full details on land [4] [5]. In total, 66 paleoseismic events, 32 liquefaction events and 19 tsunami events have been recorded. Furthermore, the application of varve dating implies that $50 \%$ of the events are dated with an annual resolution (in the 10,430 BP case even to the season of the year).

Often a liquefaction bed has lost its primary bedding stratification and becomes more or less "structure-less". This bed is often searching to vent upwards. It may contain stones and even big blocks "swimming" in the liquefied mass. Vented material mushrooms at the surface. Covering beds have a tendency to sink down into the liquefied masses (usually sand), which generates secondary space accommodation motions and deformations.

The documentation of multiple phases of liquefaction is essential; representing the main chock plus after-chocks, or multiple paleoseismic events.

Varved clay chronology is an excellent method to synchronize structures of one and the same event, as well as assigning an exact age. The turbidites are extensive and show up as useful "marker-varves" in the varve chronology.

Paleomagnetism and magnetic fabric (AMS) analyses have been applied to deformational structures (e.g. folds and wedges) of liquefaction, and have proven that the structures were formed under fluid conditions. In other sites, we have documented significantly internal "crypto-deformations" though the beds in question show no visible signs of deformation.

The tsunami events described are as many as 19, and their corresponding wave heights range from a few metres up to $20 \mathrm{~m}$. They generated extensive turbidites in the off-shore environment, the deposition of sand beds of graded bedding interrupting the normal clay and gyttja deposition in numerous lake basins, and the run-up and invasions into separate lake and bogs where a tsunamite was deposited. Whilst the deformational power seems moderate to small, their paleoseismic criteria are strong [37]. 
The key to all our deformational studies in Sweden is that every site analysis is backed up by multiple additional paleomagnetic criteria of complimentary dignity [10].

\section{Acknowledgements}

Most of the basic material here discussed has been demonstrated at major international excursions in 1999, 2008 and 2011. I quote Franck Audemard (1999) "The best liquefaction structures I ever have seen were those in Sweden. They are even better than our own type-structures in Venezuela", and Andrei Nikonov (1999) "I believe that Sweden should now be named a country of earthquakes, at least in the past, like Greece, Italy and others are named today". The work was performed in collaboration with 5 international experts (Franck Audemard, Sue Dawson, Douglas Grant, Andrej Nikonov, Dimitri Zykov) and 7 persons from our own institute (Christian Bronge, Ole Kvamsdal, Alf Sidén, Rabbe Sjöberg, Guangyu Sun, Per Erik Tröften, Hans Wigren).

\section{Conflicts of Interest}

The author declares no conflicts of interest regarding the publication of this paper.

\section{References}

[1] Cuvier, G. (1825) Discours sur les Révolutions de la surface du Globe, et sur les changements qu'elles ont produits dans le règne animal. Dufour et d'Ocagne, Paris. https://doi.org/10.5962/bhl.title.96253

[2] Lyell, C. (1830) Principles of Geology. John Murray, London. https://doi.org/10.2307/30058100

[3] Hansen, J.M. (2009) On the Origin of Natural History: Steno's Modern, But Forgotten Philosophy of Science. Bulletin of the Geological Society of Denmark, 57, 1-24. https://doi.org/10.1130/978-0-8137-1203-1-203.0.159

[4] Mörner, N.-A. (2003) Paleoseismicity of Sweden: A Novel Paradigm. A Contribution to INQUA from Its Sub-Commission on Paleoseismology at the 16th International INQUA Congress in Reno, Nevada, P \& G Print, 1-320.

[5] Mörner, N.-A. (2013) Patterns in Seismology and Palaeoseismology, and Their Application in Long-Term Hazard Assessments: The Swedish Case in View of Nuclear Waste Management. Pattern Recognition in Physics, 1, 75-89. https://doi.org/10.5194/prp-1-75-2013

[6] Mörner, N.-A. (2009) Late Holocene Earthquake Geology in Sweden. Geological Society of London, Spec. Publ. No. 316, 179-188. https://doi.org/10.1144/SP316.11

[7] Lundqvist, J. and Lagerbäck, R. (1976) The Pärve Fault: A Late-Glacial Fault in the Precambrian of Swedish Lapland. Geologiska Föreningens i Stockholm Förhandlingar, 98, 45-51. https://doi.org/10.1080/11035897609454337

[8] Lagerbäck, R. (1990) Late Quaternary Faulting and Paleoseismicity in Northern Fennoscandia, with Particular Reference to the Lansjärv Area, Northern Sweden. Geologiska Föreningens i Stockholm Förhandlingar, 112, 333-354. https://doi.org/10.1080/11035899009452733

[9] Mörner, N.-A. (2008) Paleoseismicity and Uplift of Sweden. Guidebook, Excursion 
11 at 33rd IGC, Oslo 2008, 107 p. http://www.33IGC.org

[10] Mörner, N.-A. (2011) Paleoseismology: The Application of Multiple Parameters in Four Case Studies in Sweden. Quaternary International, 242, 65-75. https://doi.org/10.1016/j.quaint.2011.03.054

[11] Mörner, N.-A. (1985) Paleoseismicity and Geodynamics in Sweden. Tectonophysics, 117, 139-153. https://doi.org/10.1016/0040-1951(85)90242-2

[12] Jacobsson, M., Björck, S., O’Regan, M., Flodén, T., Greenwood, S.L., Swärd, H., Lif, A., Ampel, L., Koyi, H. and Skelton, A. (2014) Major Earthquake at the Pleistocene-Holocene Transition in Lake Vättern, Southern Sweden. Geology, 422, 379-382. https://doi.org/10.1130/G35499.1

[13] Mörner, N.-A. (2017) Liquefaction Structures from a High-Magnitude Paleoseismic Event at about 12,400 C14-Years BP. Open Journal of Earthquake Research, 6, 216-227. https://doi.org/10.4236/ojer.2017.64014

[14] Mörner, N.-A. (2017) Methane Hydrate in Crystalline Bedrock and Explosive Methane Venting Tectonics. Earth-Science Reviews, 169, 202-212.

https://doi.org/10.1016/j.earscirev.2017.05.003

[15] Mörner, N.-A. and Sjöberg, R. (2018) Merging the Concepts of Pseudokarst and Paleoseismicity in Sweden: A Unified Theory on the Formation of Fractures, Fracture Caves, and Angular Block Heaps. International Journal of Speleology, 47, 393-405. https://doi.org/10.5038/1827-806X.47.3.2225

[16] Sjöberg, R. (1994) Bedrock Caves and Fractured Bedrock Surfaces in Sweden. Occurrence and Origin. PhD Thesis, Stockholm University, Stockholm, 1-110.

[17] Mörner, N.-A. and Sjöberg, R. (2011) Excursion Guide. 2nd International Conference on Granite Caves, 1-7 June 2011, No. 12, 1-28.

[18] Bondevik, S., Mangerud, J., Dawson, S., Dawson, A. and Lohne, Ø. (2003) Record-Breaking Height for 8000-Year-Old Tsunami in the North Atlantic. EOS, 84, 289-293. https://doi.org/10.1029/2003EO310001

[19] Hovland, M., Svensen, H., Forsberg, C.F., Johansen, H., Fichler, C., Fosså, J.H., Jonsson, R. and Rueslåtten, H. (2005) Complex Pockmarks with Carbonate-Ridges off Mid-Norway: Products of Sediment Degassing. Marine Geology, 218, 191-206. https://doi.org/10.1016/j.margeo.2005.04.005

[20] Mörner, N.-A. (2013) Drainage Varves, Seismites and Tsunamites in the Swedish Varve Chronology. GFF, 135, 308-315. https://doi.org/10.1080/11035897.2013.764546

[21] Mörner, N.-A. and Sun, G. (2013) Paleoearthquake Deformations Recorded by Magnetic Variables. Earth and Planetary Sciences Letters, 267, 495-502. https://doi.org/10.1016/j.epsl.2007.12.002

[22] Mörner, N.-A. and Tröften, P.-E. (1993) Paleoseismotectonics in Glaciated Cratonal Sweden. Zeitschriftfür Geomorphologie, 94, 107-117.

[23] Tröften, P.-E. (1997) Neotectonics and Paleoseismicity in Southern Sweden with Special Emphasis on Sedimentological Criteria. PhD Thesis, Stockholm University, Stockholm, P \& G 8, 1-124.

[24] Mörner, N.-A. (2005) An Investigation and Catalogue of Paleoseismology in Sweden. Tectonophysics, 408, 265-307. https://doi.org/10.1016/j.tecto.2005.05.039

[25] Mörner, N.-A. (2009) Liquefaction as Evidence of Paleoseismics. 1st INQUA-IGCP 567 International Workshop on Earthquake Archaeology and Paleoseismology, Baelo Claudia, Spain, 95-97.

[26] Mörner, N.-A. (1991) Intense Earthquakes and Seismotectonics as a Function of 
Glacial Isostasy. Tectonophysics, 188, 407-410. https://doi.org/10.1016/0040-1951(91)90471-4

[27] Lagerbäck, R., Sundh, M., Svedlund, J.O. and Johansson, H. (2005) Forsmark Site Investigation. Searching for Evidence of Late- or Postglacial Faulting in the Forsmark Region. SKB, R-05-51, 1-50.

[28] Lagerbäck, R. and Sundh, M. (2008) Early Holocene Faulting and Paleoseismicity in Northern Sweden. Sveriges Geologiska Undersökning, C-836.

[29] Mörner, N.-A. (2014) An M>6 Earthquake at 750 BC in SE Sweden. Open Journal of Earthquake Research, 3, 66-81. https://doi.org/10.4236/ojer.2014.32008

[30] Mörner, N.-A. (2014) Varve Chronology. In: Mörner, N.-A., Ed., Geochronology. Methods and Case Studies, Chapter 3, InTech Publ. Co., London, 73-87. https://doi.org/10.5772/58630

[31] De Geer, G. (1940) Geologia Suecia Principles. Kungl. Sv. Vet. Akad. Handl., 3rd Edition, No. 18:6, 1-360.

[32] Mörner, N.-A. (1996) Liquefaction and Varve Disturbance as Evidence of Paleoseismic Events and Tsunamis: The Autumn 10,430 BP Event in Sweden. Quaternary Science Revue, 15, 939-948. https://doi.org/10.1016/S0277-3791(96)00057-1

[33] Mörner, N.-A. and Dawson, S. (2011) Traces of Tsunami Events in Off- and On-Shore Environments. Case Studies in the Maldives, Scotland and Sweden. In: Mörner, N.-A., Ed., The Tsunami Threat. Research and Technology, Chapter 18, InTech Publ. Co., London, 371-388. https://doi.org/10.5772/13686

[34] Mörner, N.-A. (1999) Paleo-Tsunamis in Sweden. Physics and Chemistry of the Earth (B), 24, 443-448. https://doi.org/10.1016/S1464-1909(99)00026-X

[35] Mörner, N.-A., Tröften, P.E., Sjöberg, R., Grant, D., Dawson, S., Bronge, C., Kvamsdal, O. and Sidén, A. (2000) Deglacialpaleoseismicity in Sweden: The 9663 BP Iggesund Event. Quaternary Science Revue, 19, 1461-1468. https://doi.org/10.1016/S0277-3791(00)00095-0

[36] Mörner, N.-A. (2016) Tsunamis in Sweden: Occurrence and Characteristics. InTech, London, Chapter 6, 115-133. https://doi.org/10.5772/63956

[37] Mörner, N.-A. (2017) Converting Tsunami Wave Heights to Earthquake Magnitudes. Open Journal of Earthquake Research, 6, 89-97. https://doi.org/10.4236/ojer.2017.62005

[38] Mörner, N.-A. (2017) Tsunami Deposits. In: Finkl, C.W. and Makowski, C., Eds., Encyclopedia of Coastal Science, Springer, Berlin, Vol. 2, 1805-1808.

[39] Campos, C., Beck, C., Crouzet, C., Demory, F., van Welden, A. and Eris, K. (2013) Deciphering Hemipelagites from Homogenites through Anisotropy of Magnetic Susceptibility. Paleoseismic Implications (Sea of Marmara and Gulf of Corinth). Sedimentary Geology, 292, 1-14. https://doi.org/10.1016/j.sedgeo.2013.03.015 